\title{
Government Information Leaks and the First Amendment
}

\begin{abstract}
Alan M. Katz
This Comment analyzes the extent to which the first amendment protects government employees who leak government information and the press that publishes such information. After setting out the interests of the parties involved when an unauthorized leak occurs, the author suggests tests to determine the extent of first amendment protection in this area.
\end{abstract}

The executive and legislative branches of government have elaborate machinery for protecting the confidentiality of information used in pohicymaking and administration. But sometimes that machinery fails and information is disclosed to the public through unauthorized leaks by government employees. When that happens, these branches sometimes look to the courts to reassert control, either through prior restraint on publication by the press or through subsequent punishinent of the employee or the press. ${ }^{1}$ The focus of this Comment is the extent to which the first amendment ${ }^{2}$ should be used by the courts to protect gov-

$\dagger$ B.A. 1970, Duke University; J.D. 1975, Boalt Hall School of Law, University of California, Berkeley.

Part of the research for this Comment was conducted under a Boalt Hall Law Rcsearch Award.

1. See, e.g., United States v. Russo, 442 F.2d 498 (9th Cir. 1971) (criminal prosecution of alleged leakers under the espionage chapter of the federal criminal code); Bottcher v. State of Florida Department of Agriculture \& Consumer Services, 361 F. Supp. 1123 (N.D. Fla. 1973) (civil action by leaker against former employer who fired her allegedly because of a leak); New York Times Co. v. United States, 403 U.S. 713 (1971) (action by the United States government for pernianent injunction against newspapers to prohibit the publication of specific leaked docuinents); People v. Kunkin, 9 Cal. 3d 245, 507 P.2d 1392, 107 Cal. Rptr. 184 (1973) (state criminal prosecution of newspaper publisher and reporter for receiving stolen property, in this case documents containing infornation the newspaper then published); Pearson v. Dodd, 410. F.2d 701 (D.C. Cir.), cert. denied, 395 U.S. 947 (1969) (tort action for invasion of privacy and conversion against newspaper columnists who received leaked docunients and published columns based on the information in these documents).

2. As a policy issue, it is difficult to decide when a governinent employee is justified in naking public infornation that her superiors have decided should not be released. The Code of Ethics of government employees appears to require that the employee will expose corruption "wherever discovered." H.R. Con. Res. 175, 85th Cong., 1st Sess., 103 CoNg. REC. 16,297 (1957). The Code of: Ethics reads in part:

Any person in Government service should:

1. Put loyalty to the highest noral principles and to country above loyalty to persons, party, or Government department. 
ernment employees who make unauthorized leaks and the press that publishes leaked information. Part I of this Comment analyzes the interests involved in determining the extent of first amendment protection, including relevant parties' first amendment and confidentiality interests. Part II discusses the major judicial sanctions that the government seeks to use against the press, i.e., prior restraint and subsequent punishment, and the appropriate first amendment standards for the use of these sanctions. Part III examines the first amendment questions raised when the government seeks to invoke criminal, civil, or administrative sanctions against the offending employee, after an unauthorized leak.

Discussion of information leaks inost often focuses on national defense information, because national defense is the area in which the government presumably has the greatest interest in regulating the flow of information. Although the analysis in this Comment also apphies to national defense information, its focus will be on information leaked by employees of domestic agencies, e.g., disclosure that the Public Health Service Tuskegee Study was studying rather than treating some black males who had syphilis, disclosure of cost overruns in government contracts, and disclosure of political bases for antitrust enforcennent policies.

\section{I}

\section{INTRODUCTORY ANALYSIS OF LEAKS}

A "leak" by a government employee is the release, outside official public information cliannels, of previously undisclosed government information. There are two species of leaks; authorized and unauthorized. Authorized leaks are an established part of government information

9. Expose corruption wherever discovered.

This is the narrowest perimeter by which to define situations where unauthorized disclosure is necessary.

In contrast, government watchdog attorney Ralph Nader advocates "whistle-blowing" disclosure by government employees. WhISTLE BLOWING: ThE REPORT OF tHE Conference on Professional Responsibitity (R. Nader, P. Petkas \& K. Blackwell ed. 1972). Nader defines whistle-blowing in terms of the employee drawing a line where responsibility to society transcends responsibility to the organization. See Blumberg, Corporate Responsibility and the Employee's Duty of Loyalty and Obedience: A Preliminary Inquiry, 24 OKLA. L. REv. 279, 280 (1971). The People's Bicentennial Commission, among others, has advocated a position similar to Nader's, on the ground that the whistle-blower is the public's last line of defense against any government abuse of the public trust.

However, this concept has been criticized for exactly what Nader likes about it-the emphasis on individual responsibility. Critics argue that it is not the role of the employee to balance the interests at stake and to make the decision whether or not to maintain confidentiality. See, e.g., The Supreme Court, 1970 Term, 85 HARv. L. REv. 199, 211 (1971). 
policy. ${ }^{3}$ An unauthorized leak, the subject of this Comment, occurs when a government employee makes public information that her superiors and the government information machinery have chosen not to disclose. ${ }^{4}$ Whether authorized or unauthorized, leaks transmitted to the public by the media are an important source of potitical news. ${ }^{5}$

3. An authorized leak is the release of information by a government official in accordance with administration policy, but on a not-for-attribution basis. The public receives the news under a rubric such as "informed sources said" or "sources close to the President said." The overconcealment of government information makes it impossible for the government to effectively communicate with the citizenry without leaks. New York Times Co. v. United States, 403 U.S. 713 (1971) (Frankel affidavit).

The government authorizes leaks to accomplish numerous governmental purposes: to prevent an act, to instigate or further a given action, to justify an action already taken, to expose what the leaker considers to be wrongdoings of individuals, to float a trial balloon to test reaetions, or to communicate its viewpoint and imformation witlout distortion. See J. Stevens, Manipulating Secrecy 2 (Univ. of Mo. Freedom of Information Center Report No. 274, 1971), where the author suggests these categories and discusses examples of eacl. Additionally, high officials often conccal government information while in office but include it in their memoirs, which are then sold both as historical documents and for personal profit. See Hearings Before a Subcomm. of the House Comm. on Government Operations on United States Government Information Policies and Practices, 92d Cong., 1st Sess., pt. 2, 333 (1971) [hereinafter cited as 1971 Hearings] (David Wise discusses examples of ex-government officials profiting froin the sale of books containing classified information). Authorized leaking makes a mockery of information law because policy-makers enforce arbitrary criteria against others while being themselves engaged in systematically releasing self-serving news on a not-forattribution basis.

Releasing selected news to favored reporters is a long-established practice, but it was during World War II that the leak was formalized as the background briefing. Now backgrounders called by officials outnumber those instigated by reporters. L. WolfSON, The Press Covers Government: The Nixon Years from 1969 to Whtergate 31-32 (1973) (A Study by the Department of Communication, The American University, Washington, D.C., for the National Press Club) [hereinafter cited as WolfsoN]. This creates a "necessity" for the reporter and publisher to maintain a cozy relationslip with the official, thus subverting the independence of the press. Id. at 32 .

4. This Comment is limited to examining leaks by federal government employees in the executive branch. Space coustraints limit the discussion to the federal government, The executive brancl was chosen because the bulk of government information and employees are in this branch, and if the leaking of information is protected by the first amendment, leaking from one of the political branches is more likely to be protected than leaking from the judiciary. This is because it is the political nature of the information that suggests that expression might be within the scope of the first amendment, whereas in the judicial branch the analysis is different because of the paramount importance that is placed on the rights of litigants, particularly defendants in criminal cases.

5. This Comment discusses leaks to the press, but Congress may also be the recipient of leaks from the executive brancl. Generally, a government employee who provides information to Congress will come within statutorily protected rights of civil servants to petition Congress. Since Congress is more representative of diverse viewpoints, many of which diverge from administration policy, it might be thouglit that leaks to Congress of information which the administration refuses to release would be a significant source of information for the public. However, this process cannot replace the direct leak to the press for three reasons. First, because congresspersons are dependent on maintaining a working relationship with the administration to achieve enactment of 


\section{A. First Amendment and Confidentiality Interests}

Determining the extent of first amendment protection that courts should give to the employee who leaks the information and the press that publishes it requires weighing the government's and the public's interest in confidentiality against the first amendment interests of the public, press, and government employees. The public has an important first amendment interest in receiving information necessary for informed self-government. The press has a complementary interest in publishing such information. The government employee's interest is in expressing opinions and contributing information to the public discussion of issues of self-government. The process of weighing these interests involves both identifying their specific nature and determining their importance.

The government has several interests that may be threatened by the unauthorized release of government information. Eacli of these interests is both an interest of the public and an institutional interest of the government. The first and most basic is an interest in survival, which provides the classic rationale for controlling national defense information. Unauthorized leaks of information such as the technical description of a sophisticated weapon could endanger the very existence of the state, and in this sense control of leaks serves the most basic of the government's interests, which is to provide for its own security.

Second, the interest in an open decisionmaking process within the executive branch is threatened by unauthorized leaks. If leaks were protected, the inability of policymakers to trust their subordinates and have confidence in the security of documents would be an incentive to have decisions made by smaller groups of individuals with restricted outside input, with inore limited documentation, and with inore limited discussion of the subject. Thus, it can be argued that protecting leaks as a means of facilitating the flow of government information to the public would have the opposite result.

legislation, patronage, and the cooperation of federal agencies, they are rarely willing to act as a funnel for information to the public. Second, because congresspersons use leaked infornation to further their own political careers, government einployees are reluctant to communicate with the public through congresspersons. Third, because newspersons traditionally protect the secrecy of the sources of information at all costs, government employees who desire to leak information while protecting their own anonymity are more likely to place their confidence in newspersons than in legislators. Thus, while furnishing information to congresspersons who have a podium from whicl to be heard could conceivably be an important source of pohtical dialogue in the media, in practice it is limited. In addition, congressional committees have been willing to pledge, as a condition of receiving classified information, not to divulge such information to the public. In a recent incident, a nember of Congress who broke his pledge of secrecy and divulged information of a sensitive nature because he felt the disclosure was required for the country's well-being, was removed by the Speaker from a position of access to such material. Chicago Sun-Times, July 18, 1975, at 8 , col. 1 . 
A third government interest is that of efficient administration. Internal cooperation is necessary for efficient government. Policymakers must be able to trust their subordinates, and they therefore properly demand loyalty. Allowing civil servants to leak information would undermine this cooperative working relationship. An extension of this argument is that judicially condoned leaking would become a means of fighting for positions of power within the bureaucracy and would render government agencies incapable of working cohesively to carry out their funetions.

Closely akin to the interest in efficient administration is an interest in preserving the confidence of those outside government-whether private citizens or foreign states-that the integrity of their dealings with the government will be maintamed. The goverument has files concerning individuals and information on foreign governments that probably should remain confidential under any circumstances. People outside government tend to view the government as a monolithic institution, and the unauthorized release of such confidential information tends to discredit the government as a whole. The leaking of information could seriously impair the trust necessary for effective foreign policy and domestic administration.

A fimal aspect of the government's interest in effective governing is that at some point debate must cease and action be taken. The government should have sufficient institutional nechanisms for providing information to the public and for receiving public input, but the government cannot be effective unless it is able at some point to set a policy and implement it without bemg sabotaged by employees who favor a different policy. If in each government office the employees who disagreed with current policy leaked information in an attempt to cause a public furor concerning the policy, the resulting opposition to government activities would render the government ineffective.

These legitimate government interests should be distingnished from the spurious interest in concealing embarrassing or criminal-conduct information in the name of executive privilege or confidentiality. ${ }^{6}$ This spurious interest adds nothing to the weight of the government's need for confidentiality, and in some leak situations might reduce the weight that should be given to the government's interests in security, efficiency, and effectiveness.

Partly to protect these legitimate interests and partly for other reasons, government secrecy has mushroomed since World War II. The policy of wartime censorship ${ }^{7}$ was retained, and in some cases enlarged to meet the exigencies of the cold war, American international commit-

6. United States v. Nixon, 418 U.S. 683, 708-13 (1974).

7. 1 Z. Chafee, JR., Government and Mass Communications 466-68 (1947). 
ments, and the nuclear arms race. ${ }^{8}$ The interrelationship of military, economic, and political concerns has legitimized the extension of secrecy beyond national defense information. Other factors, already noted in the 1950's, are the expansion of government into new fields, the enlargement of the power of the executive branch, the complexity of issues, and greater ability to manipulate public opinion due to more effective public relations techniques. ${ }^{9}$

The first amendment interests of the public, press, and individual government employees, on the other hand, may demand the protection of at least some leaks. The public's need for information relevant to selfgovernment is a first amendment interes $\mathrm{t}^{\mathrm{10}}$ that is often furthered when leaking is protected. In periods of insecurity, the government frequently cuts off the flow of information to the citizenry by controlling public expression by employees; thus, the public's right to know depends on protecting the government employee's right to nnake public what she knows. The opinions of government employees with expertise are especially valuable to the public, particularly the opinions of dissenters.

The Founding Fathers believed that democracy is dependent on a free flow of information to the citizenry, ${ }^{11}$ and accordingly the first

8. Developments in the Law-The National Security Interest and Civil Liberties, 85 HARV. L. REv. 1130, 1195 (1972).

9. Parks, The Open Government Principle: Applying the Right to Know under the Constitution, 26 GEo. WaSH. L. Rev. 1, 2 (1957).

10. It has been postulated that the essence of the first amendment is to protect expression related to self-government. Mills v. Alabama, 384 U.S. 214, 218 (1966); New York Times Co. v. Sullivan, 376 U.S. 254, 269 (1964). The crux of this theory, developed by Alexander Meiklejohn, is that the first amendment exists to preserve popular control of the government. Meiklejohn, The First Amendment is an Absolute, 1961 Sup. Cr. Rev. 245 (1961). The source of democratic control under the Constitution is the pohitical process. The pohtical process is meaningfully democratic only insofar as there is free and thorough public discussion of the issues. Thus the private right to speak under the first amendment is intended primarily to protect the public's power. Kalven, The New York Times Case: A Note on "The Central Meaning of the First Amendment," 1964 Sur. CT. REv. 191 (1964), Meiklejohn posited that application of the first amendment should ensure that citizens have the access to all information and views useful in self-government. Meiklejohn, supra, at 255.

11. James Madison stated:

A popular government, withont popular information, or the means of acquiring it, is bnt a Prologue to a Farce or a Tragedy, or, perhaps both. Knowledge will forever govern ignorance: And a people who mean to be their own Governors, must arm themselves with the power which knowledge gives.

Letter to W.T. Barry, Aug. 4, 1822, in ThE WRITINGS OF JAMES MAdison 103 (Hunt cd. 1910), cited in EPA v. Mink, 410 U.S. 73, 110-11 (1973) (Douglas, J., dissenting). Thomas Jefferson said:

The basis of our governments being the opinion of the people, the very first object should be to keep that right.

The way to prevent [errors of] the people, is to give them full information of their affairs through the channel of the public papers, and to contrive that those papers should penetrate the wliole mass of the people.

H. LASSWELI, NATIONAL SeCuRITY AND INDividual FreEdoM 63 (1950). 
amendment was incorporated to safeguard the people's ability to receive information. ${ }^{12}$ In particular, the philosophical underpinning of the first amendment freedom of the press is that a grant of special rights to those who disseminate written words protects the ability of these individuals to serve society's interest in an uninhibited excliange of ideas and information. Justice Douglas has written:

The press has a preferred position in our constitutional scheme not to enable it to make money, not to set newsmen apart as a favored class, but to bring fulfillment to the public's right to know. The right to know is crucial to the governing powers of the people, to paraphrase Alexander Meiklejohn. Knowledge is essential to inforıned decisions. ${ }^{13}$

The immunity conferred by the first amendment is concerned more with protecting the public than with protecting the publisher..$^{14}$

The Supreme Court has not yet explicitly defined a constitutional "right to know," though the idea has been developed in recent cases dealing with the conflict between first amendment interests of broadcasters and those of advocates of a particular point of view. In Red Lion Broadcasting Co. v. F.C.C., ${ }^{15}$ the Court upheld the authority of Congress and the F.C.C. to require a radio station to provide equal reply time under the fairness doctrine to the advocate of a point of view that had been attacked in a 15-minute broadcast. The ultimate rationale for the decision was that "the right of the public to receive suitable access to social, political, esthetic, noral, and other ideas and experiences" was a inore important first amendment interest than the right of the broadcaster to air what he pleased. ${ }^{16}$ The competing first amendinent clains of broadcasters and groups seeking access to the airwaves to present political advertisements were weighed in C.B.S. v. Democratic National Committee. ${ }^{17}$ Chief Justice Burger, writing for a divided Court, suggested

Commentators have suggested various reasons why the Constitution did not explicitly protect the public's right to know. Henkin suggests that the Founding Fathers' commitment to a minimal, watchdog type of government kept them from declaring any rights which would require the government to take affirmative action. Henkin, The Right to Know and the Duty to Withhold: The Case of the Pentagon Papers, 120 U. PA. L. REv. 271, 273 (1971). Senator Hennings believed that the Framers took the public's right to know so much for granted that they deemed it unnccessary to explicitly include it in the Constitution. Hennings, Constitutional Law: The People's Right to Know, 45 A.B.A.J. 667,668 (1959).

12. New York Times Co. v. United States, 403 U.S. 713, 723-24 (1971) (Douglas, J., concurring); Curtis Publishing Co. v. Butts, 388 U.S. 130 (1967); New York Times Co. v. Sullivan, 376 U.S. 254 (1964); Patterson v. Colorado ex rel. Att'y Gen. of Colo., 205 U.S. 454 (1907).

13. Branzburg v. Hayes, 408 U.S. 665, 721 (1972) (Douglas, J., dissenting).

14. Firestone v. Time, Inc., 460 F.2d 712, 719 (5th Cir. 1972).

15. 395 U.S. 367 (1969).

16. Id. at 390 .

17. 412 U.S. 94 (1973). 
that "balancing the various First Amendment interests involved in the broadcast media" is essentially a matter of "determining what best serves the Public's right to be informed."18 Justice Brennan's dissent on the inerits is equally premised on the overriding importance of the public's riglit to a full spectrum of ideas freely presented by those who advocate thein. ${ }^{19}$

A spurious interest paralleling the public's right to know is the public desire for gossip. When an official's private life interferes with her performance of her public duties, publication of details of the private life might contribute to the citizenry's process of self-government. However, the public's desire simply to hear gossip is not a significant interest when the issue is first amendment protection of leaked government information.

The size and complexity of the federal government and the influence of the few citizens who comprise the national media will in all probability lead to development of a constitutional right to know as a distinct first amendment interest, ${ }^{20}$ similar to freedom of the press. As Judge Craven wrote, concurring in United States v. Marchetti, ${ }^{21}$ "The 'right to know' is in a period of gestation. I think that the people will increasingly insist upon knowing what their government is doing and that, because this knowledge is vital to government by the people, the 'right to know' will grow." Adoption of a first amendinent right to know would help make constitutional principles compatible with modern conditions. As it inay override a broadcaster's first amendment imterest, so under certain circumstances might the public's right to be informed override the government's interest in confidentiality.

The press has its own first amendinent interests that are furthered by the publication of leaked government infornation. These may be characterized as freedom to publish without government interference. This interest first includes publication free from government censorship, that is, without prior restraint. A slightly more complex press interest is publication without fear of government retaliation, particularly criminal and civil punishment, because such a threat creates a chilling effect on the press' free expression and can accomphish indirectly what government censorship accomphishes directly. Thus, the press' interest is in

18. Id. at 102 .

19. Id. at 172.

20. But cf. Wright, Defamation, Privacy, and the Public's Right to Know: A National Problem and a New Approach, 46 TEXAs L. REv. 630 (1968). In this article, Judge Wright discusses the inadequacy of a constitutional approach to the public's right to know in the defamation and invasion of privacy context and suggests congressional action to achieve the desired protection of the public.

21. 466 F.2d 1309, 1318-19 (4th Cir.) (Craven, J., concurring opinion), cert. denied, 409 U.S. 1063 (1972). 
having the content dictated by the press' concept of what information the public should liave rather than by any government influence over the press.

The right to gather information is a recognized part of freedom of the press. In practice, this press interest requires that the press have first amendment protection at least in publishing information voluntarily conveyed to it. This suggests a press interest in not being liable for the means used by its source to obtain information. This promotes dissemination of information froun as many points of view as possible, which is the goal of preventing government interierence with the press. Without publishing leaked information, the press would be less able to expose government corruption and inefficiency and to provide a wimdow on government decisionmaking. Advancement of the first amendment interests of the press is thus dependent on publishing leaks.

In addition to public and press first amendment interests that are served when the media publish information leaked by a government employee, constitutional protection also furthers the employee's interest in free expression. Leaking information is a government employee's way of participating in the public discussion of issues. Whether the employee releases a document or reveals similar information from memory, the process constitutes an individual brimging ler level of awareness to bear on the problems of self-government. If anything, the employee's first amendment interest in expressing political opinions may be greater because as a civil servant she is possibly better informed.

Because the government employee is vulnerable to government reprisal in many forms, she has a particularly strong interest in first amendment protection. Her first amendment interest is not only in discussing her knowledge, but also in having access to the media to distribute the information to the public that receives the government's opposing point of view and that democratically controls the government.

An unauthorized leak occurs when a government employee makes public information that her superiors and the government information machinery have cliosen not to disclose. The leaked information may have been classified for national security or administrative reasons, or withheld by the government without any legal authority. The motivation of the employee making the disclosure may vary. Leaks are often an effective ineans of influencing government policy, ${ }^{22}$ but they may also be motivated by personal vendetta agamst the employee's superior. Such personal vendetta is a spurious interest which should not weigh heavily in the first amendment balance. However, differences over policy often involve a power struggle, too. Here the courts must presumably decide whether a valid first amendment interest is at stake.

22. H. Lassweld, National SecurtTy and Indrimuac Freedom 185 (1950). 


\section{B. Government Information Policies}

Historically, pervasive government attitudes and practices, rather than statutes or executive orders, have been the obstacle to public access to government information. When practicable, information is made public only insofar as it bolsters the public image of the agency and furthers the government's policies. ${ }^{23}$ Thus, the government conceals a great deal of information which is definitely "related to the process of self-government." 24

The national security information classification system promulgated by Executive Orders 10,501 and $11,652^{25}$ states that these orders create the only system of information classification in the federal government. However, this is inaccurate. The federal government has numerous security classifications more highly confidential than Top Secret. In addition to classification of information, separate systems for administrative control of information and limited distribution of documents exist in agencies-including agencies having no relation to national security. ${ }^{26}$ Under these practices and information control systems, not only do government agencies overconceal information, but they sometimes fail to protect documents which should not be disclosed. ${ }^{27}$

The executive and legislative branches have overlaid these traditional means of dealing with information with executive orders and

23. 1971 Hearings, supra note 2 , at 266. See also Hearings on S. 1160, S. 1336, S. 1758, and S. 1879 Before the Subcomm. on Administrative Practice and Procedure of the Senate Comm. on the Judiciary, 89th Cong., 1st Sess., vol. 1, pt. A, at 266 (1965) [hereinafter cited as 1965 Sen. Hearings].

24. See note 10 supra.

25. Exec. Order No. 10,501, 3 C.F.R. 979 (1949-53 comp.), as amended, 3 C.F.R. 292 (1971), 50 U.S.C. $\S 401$ (1970); Exec. Order No. 11,652, 3 C.F.R. 339 (Supp. 1974), 50 U.S.C. $\$ 401$ (Supp. 1973).

For a summary of the history of the executive classification of documents, see Hearings on Reform of the Federal Criminal Laws Before a Subcomm. of the Senate Comm. on the Judiciary, 92d Cong., 2nd Sess., pt. 3, subpt. D, at 3063-144 (1972) [hereinafter cited as 1972 Hearings] (LIBRARY OF CONGRess, SECurtiY Classification as a Problem in the Congressional Role in Foreign Policy [hereinafter cited as SeCURITY Classification]).

26. See generally 1972 Hearings, supra note 25, at 3077 (Securuty ClassificaTroN). An example of administrative classification is "For official use only." EXDIS is an exainple of a category of limited distribution document. J. Edward Murray, in his statement on behalf of the American Society of Newspaper Editors, said that classification for reasons having nothing to do with security is the biggest problem for newspapers around the country in dealing with federal agencies. 1971 Hearings, supra note 3, at 232.

27. See, e.g., People v. Kunkin, 9 Cal. 3d 245, 507 P.2d 1392, 107 Cal. Rptr. 184 (1973), which reversed and vacated on the ground of insufficiency of evidence People v. Kunkin, 100 Cal. Rptr. 845 (1972). In this case, an einployee of the state attorney general's office gave the Los Angeles Free Press a list of names and addresses of undercover narcotics agents. The list of agents was not administratively classified and, in fact, was being distributed to government offices throughout California with extra copies being enclosed. 
statutes that attempt to balance the government's need for confidentiality against the public's need to know. Executive Order (E.O.) $10,290,{ }^{28}$ issued by President Truman in 1951, established a national security classification system for the civilian departments of the federal government. E.O. 10,290 included only vague guidelines for classifying documents and did not provide for review of the classification. To reduce the overclassification inevitable under E.O. 10,290, President Eisenhower, in 1953, issued E.O. 10,501. ${ }^{29}$ E.O. 10,501 provided for classification of documents as Top Secret, Secret, and Confidential, with each classification defined in terms of the level of threat to national defense interests that would be posed by release of the information. Forty-six departments and agencies had original authority to classify, and generally they could delegate this authority. ${ }^{30}$ Any document containing information from a classified document would automatically be classified. President Nixon issued E.O. $11,652^{31}$ in 1972 to repeal E.O. 10,501 and remedy the abuses that had occurred-basically the same overclassification abuses that E.O. 10,501 was intended to correct. E.O. 11,652 retains essentially the same criteria for classification, but reduces to twelve the number of departments and agencies with original Top Secret classification authority ${ }^{32}$ and somewhat limits the power to delegate classification authority. The most sweeping change under E.O. 11,652 is the provision for automatic declassification of documents-Top Secret after ten years, Secret after eight years, and Confidential after six years. ${ }^{33}$

Most experts agree that both E.O. 11,652 and its predecessor, E.O. 10,501 , liave failed to correct abuses in the national security classification of documents. Botli orders, through the lack of specificity of the criteria for classification, the widespread authority to classify, and the agencies' disregard of the value of public debate on the issues, allow the classification system to be abused and overused. ${ }^{34}$ For example, in the

28. Exec. Order No. 10,290, 3 C.F.R. 789 (1949-53 comp.), revoked by Exec. Order No. 10,501, 3 C.F.R. 979 (1949-53 comp.), as amended 3 C.F.R. 292 (1971), 50 U.S.C. $\$ 401(1970)$.

29. Exec. Order No. 10,501, 3 C.F.R. 979 (1949-53 comp.), as amended, 3 C.F.R. 292 (1971), 50 U.S.C. $\$ 401$ (1970).

30. It was reported in 1972 that 5,100 government officials had original Top Secret classification authority. Unknown numbers of officials possessed delegated authority for Top Secret classification, and even more had authority for Secret or Confidential classification. N.Y. Times, March 9, 1972. at 12, col. 5.

31. Exec. Order No. 11,652, 3 C.F.R. 339 (Supp. 1974), 50 U.S.C. $\S 401$ (Supp. 1973). E. O. 11,652 is to be implemented in accordance with National Security Council Directive of May 17, 1972, 37 Fed. Reg. 10053 (1972), 50 U.S.C. $\$ 401$ (Supp. 1973).

32. Exec. Order No. 11,652, \& 2, 3 C.F.R. 339 (Supp. 1974), 50 U.S.C. $\$ 401$ (Supp. 1973). Thus, it was estimated that 1,860 instead of 5,100 officials will have original Top Secret authority. N.Y. Times, March 9, 1972, at 12, col. 5.

33. Exec. Order No. 11,652, \& 5, 3 C.F.R. 339 (Supp. 1974), 50 U.S.C. $\$ 401$ (Supp. 1973).

34. 1971 Hearings, supra note 3 . Estimates as to the percentage of classified 
Department of Defense practically everyone has the authority to classify documents, and incentive for proper classification is totally lacking. ${ }^{35}$ The elastic classification system's usefulness is limited to promoting bureaucratic efficiency by directing documents through government channels.

The Freedom of Information Act (FOIA) of 1966 was enacted as a response to this excessive secrecy and as an affirmative implementation of the primciple that an informed electorate is vital. ${ }^{36}$ The philosophy of the Act is one of full disclosure by government of all information that does not fall within nine exceptions. ${ }^{37}$ This scheme was designed to achieve a workable balance of government and public interests to achieve the fullest responsible disclosure. ${ }^{38}$

documents that are improperly included within the scope of executive classification ranged from Arthur Goldberg's 75 percent, with another 15 percent that need only shortterm classification, to retired Department of Defense classification policy expert William G. Florence's 99.5 percent. 1971 Hearings, supra note 3, at 104.

A study conducted by the American University Department of Communication for the National Press Club found government employees to be thwarting access to information by obfuscation and delay under E.O. 11,652 as was typical under E.O. 10,501. WOLFSON, supra note 3 , at 18.

35. 1971 Hearings, supra note 3, at 103 (statenent of William G. Florence).

36. S. ReP. No. 813, 89th Cong., 1st Sess. 3 (1965).

37. The nine categories of information that are exceptions to the Freedom of Information Act are matters:

(1) specifically required by Executive order to be kept secret in the interest of the national defense or foreign policy;

(2) related solely to the internal personnel rules and practices of an agency;

(3) specifically exempted from disclosure by statute;

(4) trade secrets and commercial or financial information obtained from a person and privileged or confidential;

(5) inter-agency or intra-agency meinoraudums or letters which would not be available by law to a party other than an agency in kitigation with the agency; (6) personnel and medical files and similar files the disclosure of which would constitute a clearly unwarranted invasion of personal privacy;

(7) investigatory records compiled for law enforcement purposes, but only to the extent that the production of such records would $(A)$ interfere with enforcement proceedings, (B) deprive a person of a right to a fair trial or an impartial adjudication, (C) constitute an unwarranted invasion of personal privacy, (D) disclose the identity of a confidential source and, in the case of a record compiled by a criminal law enforcement authority in the course of a criminal investigation, or by an agency conducting a lawful national security intelligence investigation, confidential information furnished only by the confidential source, (E) disclose investigative techniques and procedures, or (F) endanger the life or physical safety of law enforcement personnel. [as amended Nov. 21, 1974];

(8) contained in or related to examination, operating, or condition reports prepared by, on behaif of, or for the use of an agency responsible for the regulation or supervision of financial institutions; or

(9) geological and geophysical information and data, including maps, concerning wells.

5 U.S.C. $\$ 552(\mathrm{~b})$, as amended Pub. L. No. 93-502, $\$$ 1-3, November 21, 1974, 88

Stat. 1561-64.

38. S. ReP. No. 813 , 89th Cong., 1st Sess. 3 (1965). 
Professor Kenneth Davis correctly predicted before enforcement of the FOIA began that, even under the assumption that the Act would be obeyed, the information that would be opened would be minimal. ${ }^{30}$ The loose statutory language describing the exceptions to the disclosure requirement ${ }^{40}$ and the absence of uniform regulations for agency implementation $^{41}$ have fostered excessive withholding. More importantly, any phrasing of the exceptions broad enough to include all information that the executive should be able to keep conficlential, necessarily must be so broad as to cover information that the executive has no legitimate reason to withhold. ${ }^{42}$

In addition to the difficulties with the language of the FOIA, a congressional study has characterized the first five years of implementation of the Act as bureaucratic footdragging. ${ }^{43}$ An inherent problem is that the people who classify the documents are those who have consistently opposed legislation concerned with freedoin of information. Given this fact, it is inevitable that the need for conficlentiahty will be overemphasized. ${ }^{44}$

In Environmental Protection Agency v. Mink, ${ }^{45}$ the Supreme Court further limited the potential for release of niformation under the FOIA. In what it viewed as a strict statutory interpretation, the Court held that the Act's first exemption does not permit challenges to the classification of documents under E.O. 10,501 $(11,652)$ and that in camera inspection is not an appropriate means for determining whether factual parts of documents withheld under the fifth exemption of the Act could be released without exposing the decisionmaking process. ${ }^{40}$

39. Davis, The Information Act: A Preliminary Analysis, 34 U. CHr. L. Rev. 761, 803 (1967).

40. Katz, The Games Bureaucrats Play: Hide and Seek under the Freedom of Information Act, 48 TexAs L. REv. 1261, 1262 (1970).

41. Giannella, Agency Procedures Implementing the Freedom of Information Act: A Proposal for Uniform Regulations, 23 AD. L. REv. 217, 220 (1971).

42. For example, the key information in the exposure of various government scandals such as tax scandals, the Dixon-Yates scandal, the stockpiling scandals, and the Billie Sol Estes scandal would fit within the fifth exception to the Freedom of Information Act, "intra-agency or inter-agency memorandums or letters dealing solely with matters of law or policy." See 1965 Sen. Hearings, supra note 23, at 535 (statement of Ralph Sewell on belnalf of Sigma Delta Chi).

43. WolfsoN, supra note 3 , at 17 . In an analogous situation, federal agencies are providing strong opposition to current congressional efforts to require such agencies to make their regulatory decisions at public meetings announced in advance. Wall St. J., Sept. 23, 1975, at 1, col. 1 .

44. The government, through the Justice Department, went to court morc than forty times in the first Nixon administration to prevent the release of information under the Freedom of Information Act. This further polarizes the governinent as an opponent of the Act. Wolfson, supra note 3, at 17.

45. 410 U.S. 73 (1973).

46. Id. at 81,93 . While Mink deals only with the first and fifth exceptions, these are two of the broader exceptions, see note 34 supra, and, as the first Supreme Court 
Although Congress has now amended the FOIA to reverse the in camera inspection holding in Mink, ${ }^{47}$ the case remains as the leading Supreme Court interpretation of the FOIA. Congress sought to achieve limited objectives with the FOIA, but the Mink decision undercuts even these. ${ }^{48}$

It is thus clear that the FOIA can provide, at best, only a limited remedy to the problem of excessive government secrecy. The Act as drafted, enforced, and interpreted does hittle to improve public access to information about political issues. ${ }^{49}$ More importantly, the concept underlying the Act is faulty and has proven self-defeating. A statute that allows withholding of information that fits within broad categories of exceptions cannot protect the public from overconcealment. ${ }^{50}$ Moreover, a statute that requires an individual to request specific documents cannot afford the means for the citizenry to be well-informed. ${ }^{51}$

The inadequte dissemination of information seems to be inherent in American government. Official regulations, including the FOIA and national security classification, protect confidentiality rather than promoting or protecting disclosure. They do not fulfill the function of balancing the need for confidentiality with the national interest in a free flow of information. Moreover, without a desire to reform information policies within the executive branch itself, legislative guidelines and classification categories cannot succeed in providing increased public access to information.

The attitudes of government administrators do not appear likely to

case under the Act, Mink will color all judicial interpretation of the Act. But cf. Alfred A. Knopf, Inc. v. Colby, 509 F.2d 1362, 1367 (4th Cir. 1975); Vaughn v. Rosen, 484 F.2d 820 (D.C. Cir. 1973), cert. denied, 415 U.S. 977 (1974).

(1970).

47. Pub. L. No. 93-502; H.R. 12471, 93d Cong. (1974); 5 U.S.C. $\$ 552$ (a) (4) (B)

48. See Environmental Protection Agency v. Mink, 410 U.S. 73, 104 (1973) (Brennan, J., dissenting); Developments in the Law-The National Security Interest and Civil Liberties, supra note 8, at 1224. Justice Stewart, concurring in Mink, agreed that Mink prevented disclosnre in precisely the situations which should be opened to fullest disclosure, but he believed that congressional drafting, not narrow judicial construction, produced this result. 410 U.S. at 95 (Stewart, J., concurring).

49. In fact, the bulk of the suits brought under the FOIA have been prosecuted on behalf of private interests. The strongest argument made in support of the Act's accomplishments is that, while the specific procedures created for information release have not proven useful, bureaucrats often release the information when threatened with a law suit under the Act. Benny L. Kass, former counsel to the House Foreign Operations and Government Information Subcommittee, testified that in ninety percent of the cases the threat of a lawsuit gets the government to release the information sought. 1971 Hearings, supra note 3 , at 308.

50. See text accoinpanying note 42 supra.

51. Most of the time a member of the public does not know the nature of the material that she wants to have declassified. 1971 Hearings, supra note 3, at 259 (statement of John R. Callahan on behalf of the Editorial Committee of the American Business Press). 
evolve in the direction of greater sympathy for the release of information. American international involveinent will continue, the government will continue employing sophisticated public relations techniques, and the complexity of issues will grow. Also, with the increasing reliance on decisionmaking by a technocratic elite using cybernation, the electorate has an increasing need to know what information is being placed in computers. Moreover, cybernation has produced an implosion of infornıation upon whiclı government decisionmaking is based, and public access to data must accelerate for the citizen to inaintain the same relative position vis-à-vis the official. Thus, public access to internal government documents and data will become more and more important. Some observers fear that the evergrowing bureaucracy will increasingly smother newsworthy information. ${ }^{52}$

\section{II}

\section{The Press}

\section{A. Judicial Censorship - The Doctrine of Prior Restraint}

On rare occasions, the government lias asked a court to enjoin publication of leaked information and thus to act as a censor. ${ }^{.3}$ The occasions when a court has actually done so are even more rare. For, with the exception of "a single, extreinely narrow class of cases," prior restraint is generally held to be incompatible with the freedom of the press guaranteed by the first amendment. As Chief Justice Hughes said in Near v. Minnesota ${ }^{54}$ "the chief purpose of [the first amendinent's] guaranty [is] to prevent previous restraints upon publication." The reason cited most often to support this proposition is that freedoin of the press protects the ultimate first amendment interest of the public-its right to know. Prior restraint would prevent the timely dissemination of

52. The Twentieth Century Fund Task Force on the Government and the Press reported its findings that the press does have this fear. F. GrahMM, Press FreEdoms UNDER PRESSURE 116 (1972).

53. So strong is the prohibition in American law against prior restraint that there appears to have been only one instance in our history when the government has sought to enjoin publication of leaked information by a newspaper. New York Times Co. v. United States, 403 U.S. 713, 725 (1971) (Brennan, J., concurring). The government has sought to restram publication of a book on the ground that it contained classified information. United States v. Marchetti, 466 F.2d 1309 (4th Cir.), cert. denied, 409 U.S. 1063 (1972) (for a discussion of this case, see text accompanying notes 126-29 infra). The government generally lacks advance knowledge as to what the press intends to publish. The publication of the Pentagon Papers was one of those unusual news stories that was serialized. In contrast, the Chicago Tribune story early in World War II disclosing that the United States had broken the code by which Japan transmitted its secret military and diplomatic messages, once published, left nothing that could be usefully restrained.

54. 283 U.S. 697,713 (1930). 
information from competing points of view, and allow the government to control the public's sources of news. The constitutional prohibition against prior restraint thus protects the marketplace of ideas in which competing poimts of view struggle for popular acceptance. ${ }^{55}$ If the government could constitutionally prevent publication, it could institute the type of policing operation that would ultimately allow it to close down the marketplace altogether and replace it with a company store. ${ }^{56}$

Despite the presumption against the validity of prior restraints on publication, the government is still free to seek them, and no court has said that prior restraint can never be justified. Thus, the question of what circumstances justify a prior restramt remains open. What standard or burden must the government meet before prior restraint may be ordered? For 40 years, until New York Times Co. v. United States ${ }^{57}$ (the Pentagon Papers case), the leading judicial statement on prior restraint was Near $v$. Minnesota ${ }^{58}$ which involved an attempt to use Minnesota's Gag Law to suppress the publication of a defamatory antiSemitic newspaper. In a dictum in Near, Chief Justice Hughes, citing examples of situations in which prior restraint might be permissible, wrote that in time of war: "a government might prevent actual obstruction to its military recruiting service or the publication of the sailing dates of transports or the number and location of troops. . . . The security of the community life may be protected against incitements to acts of violence and the overthrow by force of orderly government."59 The dangers which Hughes found to justify prior restraint are best characterized by their gravity and imminence. ${ }^{60}$

It was widely expected that the Near standard would be updated when the Supreme Court decided the Pentagon Papers case in $1971 .^{61}$ The Court found that inpending publication of the classified, national defense information contained in the Pentagon Papers did not justify prior restraint. The 6-3, three paragraph per curiam opinion confirms that only the most exceptional circumstances will justify a prior re-

55. Probably the most eloquent judicial statement of this philosophy was by Learned Hand in United States v. Associated Press, 52 F. Supp. 362, 372 (S.D.N.Y. 1943), aff'd, 326 U.S. 1 (1945).

56. New York Times Co. v. United States, 403 U.S. 713, 733-34 (1971) (White, J., concurring) (discussion of Congress' unwillingness to give the executive the power to monitor the press under the 1917 Espionage Act).

57. 403 U.S. 713 (1971).

58. 283 U.S. 697 (1931).

59. Id. at 716 .

60. United States v. New York Times Co., 444 F.2d 544, (2d Cir.), rev'd, 403 U.S. 713 (1971).

61. New York Times Co. v. Umited States, 403 U.S. 713 (1971). For a discussion of a recent British case denying the British government's attempt to enjoin the publication of a deceased Cabinet minister's diaries and limiting government restrictions of the press, see N.Y. Times, Oct. 2, 1975, at 1, col. 1. 
straint, but sheds little new light on the question of what circumstances would be sufficient. The Court contented itself with the unadorned observations that: (1) there is a heavy presumption against the constitutional validity of any system of prior restraint; (2) the government must thus meet a heavy burden in seeking suclı restraint; and (3) it had not met that burden. Just what that burden was, the Court judiciously declined to say. ${ }^{62}$

Nor did the individual concurring or dissenting opimions offer any substantial standards to improve on Near. The Second Circuit correctly generalized Near and applied to the documents a "grave and imınediate" danger test. ${ }^{63}$ The government argued that this should be interpreted as a "grave and irreparable harm" test. ${ }^{64}$ The American Civil Liberties Umion, as amicus for the New York Times Co., urged that the government be required to satisfy a two-part test: (1) useful to the enemy, and (2) not contributing to political discussion. ${ }^{65}$ Justice Brennan interpreted the Near test to mean that "only government allegation and proof that publication must inevitably, directly, and immediately cause the occurrence of an event kindred to imperiling the safety of a transport already at sea [in time of war] can support even the issuance of an interim restraining order." ${ }^{\prime 6}$ In dissent, Justice Blackmun called for a "weighing, upon properly developed standards, of the broad right of the press to print and of the very narrow right of the government to prevent. Such standards are not yet developed." ${ }^{\prime \prime}$ In concluding, Blackmun merely noted the "harm" test elaborated by Judge Wilkey in his dissent in the companion Washington Post case: the imminent threat of "the death of soldiers, the destruction of alliances, the greatly increased difficulty of negotiation with our enemies, the inability of our diplomats to negotiate. . .."

All of the suggested tests focus on the threat to national security posed by release of the specific sensitive information involved, rather than on a possible threat to government interests in free discussion within government and in efficient admimistration. This limiting of the government interest that can give constitutional validity to a prior

62. 403 U.S. at 714.

63. United States v. New York Times Co., 444 F.2d 544 (2d Cir.), rev'd, 403 U.S. 713 (1971).

64. 403 U.S. 713, 732 (1971).

65. Brief for American Civil Liberties Union as Amicus Curiae at 12-13, New York Times Co. v. United States, 403 U.S. 713 (1971).

66. New York Times Co. v. United States, 403 U.S. 713, 726-27 (1971) (Brennan, J., concurring).

67. Id. at 761 .

68. Id. at 763, quoting Wilkey, J., who concurred in the companion case, United States v. Washington Post, 446 F.2d 1327, 1330 (D.C. Cir. 1971), aff'd, 403 U.S. 713 (1971). 
restraint is suggested by Near and is consistent with the judicially accepted rationale that the primary goal of the first amendment is to prohibit prior restraint of expression. ${ }^{69}$

The Court in the Pentagon Papers case considered the means by which the informants gained possession of the Pentagon Papers to be irrelevant to the question whether publication should be enjoined. Theoretically, this could encourage the use of illegal means to obtain information. ${ }^{70}$ Additionally, the official who controls the information whicls is leaked is generally without remedy against the press. ${ }^{71}$ However, if information has been obtamed illegally, such as through wiretapping, the perpetrator of the crime is punishable by the government. ${ }^{72}$ Evidence of misconduct by government officials is so difficult to obtain, and its publication is so important, that the press should not be held accountable for the means used by the informant in obtaining the information. The balance weighs in favor of not allowing prior restraint on grounds that illegal means were used by the press' informant to obtain the information or that leaking it to the press was illegal.

\section{B. Criminal Prosecution of the Press After Publication}

The second way in which the government tries to use courts to discourage publication of leaked information is criminal prosecution of the offending newspaper or media. Two theories have been suggested under which those who publish leaked information may be criminally prosecuted. First, the Espionage Act expressly prohibits unauthorized use of certain kinds of government information. Second, on the theory that information is property, the unauthorized transfer of information may be a property crime. ${ }^{73}$

69. New York Times Co. v. United States, 403 U.S. 713, 724 (1971) (Douglas, J., concurring). See note 10 supra.

70. The distinction should be drawn between receiving information by leak and receiving information by an illegal means such as a wiretap. An analogy can be drawn between information sources for law enforcement and for the press. While the Constitution and statutes limit the police in using searches and seizures to gather imformation in an imvestigation, the police can seek information from other people no matter how the others obtained the information. The ueighbor who was most directly invading the suspect's privacy is probably the person the police most want to question. Both the police and the press serve a public purpose; while they must observe certain restrictions while accoinphishing this purpose on their own, they should be free to use auy information furnished to thein by others in accomplishing the public purpose. (1969).

71. See Pearson v. Dodd, 410 F.2d 701 (D.C. Cir.), cert. denied, 395 U.S. 947

72. This is particularly true in light of Branzburg v. Hayes, 408 U.S. 665 (1972) which permitted grand juries to question reporters as to the identity of their sources and made it more likely that illegal sources would be identified.

73. For example, the defendants in People v. Kunkin, 9 Cal. 3d 245, 507 P.2d 1392, 107 Cal. Rptr. 184 (1973), were prosecuted for receipt of stolen property. However, there is some debate as to whether unauthorized release or receipt for 
Consonant with these theories, state legislatures and the Congress have enacted government information regulations and sanctions for violating such regulations. Prosecution of the press for publishing government documents might be based on criminal theft statutes designed to protect government property. The press might also be prosecuted under the federal espionage ${ }^{74}$ and confidentiality laws, ${ }^{75}$ public property law, ${ }^{76}$ or a records law. ${ }^{77}$ The proposed federal criminal code drafted by the Nixon administration and supported by the Ford administration includes a provision for post-publication punishment of media that print leaked documents. ${ }^{78}$

Although criminal prosecution of the news media under the espionage laws is uncommon, the first amendment would not bar such prosecution under certain circumstances. The individual opinions of three of the justices in the Pentagon Papers case suggested that the government would have had to meet a less restrictive first amendment standard if it had prosecuted the New York Times and Washington Post under the espionage laws rather than seeking an injunction against publication. ${ }^{70}$

The nonconsticutional limits on punishment of the press for a property crime when leaked government information is published are more problematic. The leading federal case on whether government documents are within the law of property is Pearson v. Dodd, ${ }^{80}$ which holds that publication of leaked papers belonging to a United States Senator is not punishable as a conversion of property. The court reasoned that to qualify as property, the information leaked must have literary, scien-

publication of government information is punishable under existing federal statutes. See, e.g., Nimmer, National Security Secrets v. Free Speech: The lssues Left Undecided in the Ellsberg Case, 26 Stan. L. REv. 311 (1974); Edgar \&: Schmidt, Jr., The Espionage Statutes and Publication of Defense Information, 73 ColUM. L. Rev. 929 (1973). No leaker has yet been convicted of a crime under these federal statutes or under any state statutes.

74. 18 U.S.C. $\S \S 793-98$ (1970).

75. 18 U.S.C. $\$ \$ 1902-08(1970)$.

76. 18 U.S.C. $\S 641$ (1970).

77. 18 U.S.C. $\$ 2071(1970)$.

78. S. 1, 93d Cong., 1st Sess. (1973); S. 1400, 93d Cong., 1st Sess. (1973). Congress has not yet enacted a criminal statute and questions of constitutionality have not yet been answered.

79. New York Times Co. v. United States, 403 U.S. 713, 727, 730, 740 (1971) (separate opinions of Stewart, J., White, J., and Marshall, J.).

80. 410 F.2d 701 (D.C. Cir.), cert. denied 395 U.S. 947 (1969). Former and present employees of Senator Thomas Dodd made copies of letters, office records and other documents in the Senator's files and gave the copies to syndicated columnists Drew Pearson and Jack Anderson who subseqnently published some of the information. Dodd sued the columnists for invasion of privacy and conversion. Judge Skelly Wright writing for the Court of Appeals fonnd that the defendants did not commit a conversion of the docnments because Senator Dodd was not deprived of his use of them. 
tific, or commercial value that depends on its being kept secret. ${ }^{81}$ Not only was the information outside of the definition of property, ${ }^{82}$ but also, because Senator Dodd was not deprived of the use of the documents, he failed to establish the elements necessary to recover for tortious conversion. The court suggested that the appropriate action for the plaintiff was for invasion of privacy or defamation, though it hinted that even here recovery might be barred by common law and constitutional defenses. ${ }^{83}$ The court did not reach the question of first amendment defenses.

Arguably, it is difficult to generalize from the Pearson case because: (1) as a civil suit rather than a criminal prosecution of the press, first amendment defenses were not applicable in the same way; and (2) the documents were not government documents as such, but consisted of personal documents relating to Dodd's official position. However, the extensive elaboration by the Supreme Court of first amendment protection of the press in civil defamation suits demonstrates that tort liability arising out of publication is restricted by the first amendment just as is criminal hability. ${ }^{84}$ As to whether Senator Dodd's files were private as distinguished from government documents, the court referred to the private information contaimed in Senator Dodd's files ${ }^{85}$ but did not base its analysis on the distinction between public and private information or documents. Defining property by a value standard produces the same result under either analysis - the information is not subject to the laws of property. Senator Dodd controlled this information just as some government official controls any government information. Even if Dodd's docuinents were private and not government, Pearson is instructive regarding whether press publication of government information violates prohibitions agamst larceny and conversion, because the argument that government documents are not property is even stronger than the argument that private documents are not property.

A state case regarding whether government documents are within the law of property is People v. Kunkin, ${ }^{86}$ which involved a state

81. 410 F.2d at 708.

82. See Liberty Lobby, Inc. v. Pearson, 390 F.2d 489, 492 (D.C. Cir. 1968) (Wright, J., concurring), where Liberty Lobby, Inc. sought an injunction against publication of information from its files. Judge Wright rejected the argunent that the lobbying association had a property interest, not compensable with money, in copies of the documents.

83. 410 F.2d at 708; cf. New York Times Co. v. Sullivan, 376 U.S. 254 (1964).

84. New York Times Co. v. Sullivan, 376 U.S. 254 (1964).

85. 410 F.2d at 706, n.23.

86. 100 Cal. Rptr. 845 (2d Dist. 1972), rev'd on other grounds, 9 Cal. 3d 245, 507 P.2d 1392, 107 Cal. Rptr. 184 (1973). The California Supreme Court reversed the conviction on the ground of insufficiency of evidence and, therefore, never reached the issues being discussed. For the purposes of the decision, the California Supreme Court assumed, without deciding, that the government document was property. Heremafter, 
prosecution of the Los Angeles Free Press, its publisher, and one of its reporters for receiving stolen government property consisting of a roster of undercover agents working for the California Bureau of Narcotic Enforcement. Kunkin held that the document had value, and that it was property and not information as the defendants argued. The California Second District Court of Appeal distinguished Pearson as relating to conversion rather than stolen property, and so avoided confrontation with the force of the Pearson opinion. ${ }^{87}$ In Kunkin, whether the roster of undercover agents was property turned on whether it had value. The court found that it had value in four senses: (1) the sheets of paper had value; (2) the preparation, assembly, and distribution of the docunient reflected costs and thus value; (3) the roster had value as a compilation of information, analogous to a list of telephone subscribers that has commercial value; and (4) there was some evidence that the Los Angeles Free Press considered paying 20 dollars for the roster, although no such payment was made. ${ }^{88}$ The court of appeal rejected first amendment claims raised by the defendants.

Although the courts in Pearson and Kunkin reached opposite conclusions as to whether the government documents that had been leaked to the press were property, they agreed that resolution of the question turns on whether the documents have value. The Kunkin court gave value a broad meaning so that the value of the paper as paper, if not the value of the information, requires that government docuinents be protected by the law of property. Value under Pearson is limited to commercial value for which the government intended to use the information. Thus, under the Kunkin test, whenever a copy of a document is passed to the press the government's property rights are violated, but if the information is passed by telephone no property interest is automatically violated. The court justified drawing the line at this point on the basis of efficiency in enforcement and protection of government information. The line is easily drawn and creates a significant obstacle to unauthorized leaking of information, but its deficiency is too glaring to be overlooked. Documents have value to the public, the press, and most importantly to the government not because of the paper on which they are printed, but rather because of the information contained therein. Thus, the inforination should either have value so as to qualify as

references to the Kunkin case will refer to the decision of the California Court of Appeal. The stolen property in question was one copy of a list of the names, addresses, and telephone numbers of California's undercover narcotics agents. An employee at the Los Angeles office of the state attorney general gave the list to the Free Press which subsequently published the information.

87. 100 Cal. Rptr. at 854-55, rev'd on other grounds, 9 Cal. 3d 245, 507 P.2d 1392, 107 Cal. Rptr. 184 (1973).

88. Id. at $850-51$. 
property no matter in what form it is leaked, or the information should not qualify as property under any circumstances. ${ }^{89}$ Pearson is on sound footing, both in terms of judicial precedent and social policy, in concluding that government information not being held for its commercial value does not fall under the protection of the law of property.

Under whatever theory a prosecution is brought, the first amendment limits Congress' ability to punish the press criminally for publication of leaked government information. But the standard that the government must meet before punishment nnay be imposed is not clear. Congress has either tacitly or explicitly authorized an executive branch classification system and criminal sanctions for violating it. But the legislative and executive branches have virtually unfettered discretion in implementing standards for classification, and such latitude is unacceptably overbroad as a first amendment standard for punishment of receiving and publishimg leaked government information. The classification systen itself cannot serve as the first amendment standard, since this would mean that a determination of when the press is punishable would rest simply on the inajority will of the legislature, or the caprice of the executive. Any system of classification may include information the publication of which could not be restramed by an injunction. Additionally, any classification system will probably be abused by overuse. Further, various legislation protects the confidentiality of different amounts of information, but the first amendment should not vary with the statute then in force. A first amendment standard different from congressionally created information classification systems must be developed to limit the government's ability to punish the press for publication of leaked information.

Such a standard should take account of at least five considerations, three of which are directly related to the purposes of the first amendment. First, it should focus on the appropriate role of the press in providing the public with information useful in self-government. Second, it should not discriminate based on political beliefs. Third, it should give maximun feasible protection to the public's right to know. Fourth, though not a first amendment consideration, it should provide some deterrent against the press' exposing properly secret information And lastly, it should provide a basis on which the media can predict

89. Because corporate documents are copyrightable, if they are taken by an employee, she can be prosecuted for theft and the corporation has a civil remedy for conversion. However, federal statutory law forbids copyrighting government documents. 17 U.S.C. $\& 8$ (1970). Further, the Register of Copyrights has noted that "control over the unauthorized dissemination of unpnblished Government Works should be dealt with as a matter of security rather than hiterary property." COPYRIGHT LAW Revision, PART 6, House Comm. on THE Judiciary, 89th Cong., 1st Sess. at 9 (Comm. Print 1965). Thus copyright law supports the position that government docnments are not property. 
their liability from their actions. There are at least three possible standards for determining the constitutionality of prosecuting the press for publishing documents obtained via an unauthorized leak.

First, tests based upon the content of the information are possible. Similar to the prior restraint area, one approach under this kind of test would be to allow prosecution of the media whenever a court finds that the published information presents a danger to the state. But this type of content analysis fails to consider the first amendment role of the press because it ignores whatever value the information might have for public discussion. Alternatively, the content of the information could be judged solely by its usefulness for public discussion. Prosecution of the media would be prolnibited unless a court determines that the information contributes little or nothing to the self-governing process. This approach, however, neglects completely the interest of the state in secrecy. Adoption of either approach to the content test would create a deterrent effect upon publication of information conceivably within the prohibited range. Since the press could not, by a good faith behef that publication was proper, immunize itself from prosecution, a chilling effect would be created whenever substantial doubt existed.

A second possible test is a balancing test-balancing the government's interest in secrecy against the public's imterest in having access to information. However, balancing tests can always be criticized for failing to provide predictability. This uncertainty is likely to destroy much of the protection of society's interest in use of the information in the selfgoverning process because of the chilling effect problem already discussed. Balancing also places too much empliasis upon the political beliefs of the court that must determine the value of the leaked information's content in the self-government process.

In order to properly take into account all five considerations previously discussed, the first amendinent should be held to prohibit prosecution of one who publishes leaked information absent a showing that the publisher leld some improper state of mind as to the content of the information published. A subjective test is necessary to avoid undesirable self-censorslip by the press in an attempt to avoid prosecution.

An appropriate subjective test for punishing publication of leaks, includimg national security information, night be to determine if the information was published "in reckless disregard of the excessive harm to the governinental interests contrasted with the lack of value for the public in self-governing." ${ }^{\text {"go }}$ The first amendinent does not protect the

90. It would, of course, be possible to have a subjective test that permitted prosecution if the publisher were merely negligent in disregarding the balance of values connected with publicatiou of the information. But this creates problems of uncertainty, and thus forfeits the main advantage of a subjective test. 
publisher of leaked information if: (1) the public's interest in maintaining the secrecy of the information outweighs the public's interest in receiving the information and (2) the publisher, taking into consideration her constitutional duty of providing the public with the information useful for self-governing, recklessly disregards the balance against disclosure. By having the court balance the coinpeting first amendment and government confidentiality interests, this standard requires that the publisher take into account the interests opposing the public right to know. However, to prevent the specter of criminal punishment from restraining the press that in good faith believes that publication serves the public interest, punishment should only be constitutionally permissible if the decision to publish was inade in reckless disregard of the overriding importance of maintaining confidentiality. Protecting the press with a subjective standard is necessary to avoid the chilling effect and desirable to preserve the press' unique capability of informing the public.

A first amendment standard based on the publisher's state of mind concerning content was first applied to the press in defamation cases and subsequently expanded to invasion of privacy actions. ${ }^{91}$ The governinent's interest in confidentiality can be analyzed and weighed in nuch the same way as a private citizen's interest in reputation or privacy. A court nust balance the interests in reputation, privacy or confidentiality against the public's right to know, the government employee's right to free expresison, and the press' right to publish. Unlike defamation cases, however, truth or falsity is not the primary issue when government information is leaked, because the government's interests are threatened whether the information leaked is true or false. The issue that the press inust not recklessly disregard is the injury to the national interest resulting from disclosure. Proof of harm to the national defense or other strong national imterest inight be equivalent to the proof of damages necessary to recover for defamation.

Two problems appear to plague the "reckless disregard of the balance of interests" standard. First, despite the strong presumption against the validity of prior restraints, this standard might prevent punishment of the press in sone situations in which prior restraint would be constitutionally permissible. A docunient may both contribute to the public discussion of the issues and create a grave and imminent danger to the nation. Publication of such a document would be restrain-

A stricter standard than the one proposed could also be adopted: a publisher could not be prosecuted unless he knowingly disregarded the excessive harm from publicatiou. In certain circumstances, lowever, this would preveut authorities from punishing behavior which nearly all would agree is dangerous.

91. See Gertz v. Robert Welch, Inc., 418 U.S. 323 (1974) (defamation); Time, Inc. v. Hill, 385 U.S. 374 (1967) (invasion of privacy); New York Times Co. v. Sullivan, 376 U.S. 254 (1964) (defamation). 
able, but punishment of the press would be constitutionally impermissible. Such a situation is rare. It would seem that if a court enjoins publication of particular leaked information and the media goes ahead and publishes it, the media would then be punishable for contempt of court. Allowing prior restraint of information when its publication would not result in punishment of the press is justifiable because of the different social policies supporting prior restraint and pumshment: restraint serves to protect a government secrecy interest, whereas punishment forces the press to be responsible in fulfilling its function of keeping the public informed. If the press in trying to carry out this function is not reckless, it should not be punished. ${ }^{92}$

The second problein with the proposed state of mind constitutional standard for criminal conviction of the press is that it might not sufficiently protect the government's interest im confidentiality. When a leak occurs, the government usually does not have the warning necessary to go to court for an imjunction before publication. Thus, disallowing punishment leaves the media undeterred froin primting potentially dangerous information that is of use in public discussion.

No line is without its social costs, but this line seems to be the least costly. In protecting both the freedom of the press and government secrecy, the government because of its control over the information, its possible adverse action against the employee who leaks information, and its ability to manage news, is better able to bear the burden of constitutional restrictions. ${ }^{93}$

Regardless of the test used, the question arises regarding the relevancy of the government's classification system. Under New York Times Co. v. United States, ${ }^{94}$ whether or not the leaked information was classified is irrelevant im the courts determination of whether prior

92. Although the government's interest in secrecy should be considered, the press will be unable to guarantee the public's right to know if it can be punished simply for failure to take into account a competing interest. To reduce the chilling effect on first amendment expression and ensure the press' ability to protect the public's right to know, constitutionally permissible punishment is limited to situations of reckless disregard.

93. This test, by allowing criminal punishment of reckless and deliberately irresponsible actions by the press, should reduce the incentive for the government to resort to illegitimate means for controlling the content of publication, either through pressuring the inedia or relying on the implicit threat of doing so. The government can do this by granting competing media greater access to government news sources, licensing of broadcast media, anti-trnst and other court actions, tax evasion and other investigations, and pressure on advertisers, upon whom most media depend. This is not to condone the use of such illegal means to inhibit the press, but only to acknowledge that possible resort to such tactics by the government is a source of power which chills the press and is a course of action not to be encouraged.

94. 403 U.S. 713 (1971). 
restraint of the press is constitutionally permissible. ${ }^{95}$ This result should equally follow for criminal punishment ${ }^{96}$ because classification is often unrelated to the necessity of maintaining the confidentiality of the content of the information, and because classification generally occurs without regard to any contribution the information might make to public discussion. The arbitrary nature of classification also means that the government may be unable to protect its security interests if punishment is impermissible just because information is not classified. Under Chief Justice Hughes' troop movement or ship embarkation examples, the government's ability to punish the media that publishes such information should not depend on whether the document bore a classification stamp. Conversely, the government relies on executive classification to prevent enibarrassment, hide corruption, and hide imefficiency. ${ }^{97} \mathrm{~A}$ press criminally liable for publication of such classified information cannot achieve one of its purposes that the first amendnient protects, i.e., to prevent deception. ${ }^{98}$

The foregoing analysis suggests that punishment on the basis of the existing classification system is unconstitutional under the first amendnient. If classification is limited to use as a tool for channeling information within the bureaucracies, the system is permissible. But if violation of the classification system is statutorily determined to be a basis for criminal conviction of the press, the system should be declared unconstitutional. Infringement of the flow of information to the public under a classification system is justifiable under the first amendment only if neither the press nor government employees lose their rights to disseminate information. Even if the government limited classification to documents containing only technical information-and even assuming such information is of no use in self-government-and looked to the usefulness of the information to the public before classifying, using the classification systen as a limit on information dissemination to the

95. The Pentagon Papers were national security classified documents, but quite possibly were improperly included within the scope of E.O. 10501. 1971 Hearings, supra note 3, at 105-06 (statement of William G. Florence). Even so, only six of the Justices voted against prior restraint. The other Justices were mistakenly influenced by the classification.

96. The one exception to the rule that classification is irrelevant to the issue of the constitutionality of a subsequent punishment is that the status of information as classified might be evidence of the knowing nature of the press's disregard of the information's lack of value to the public in self-government. Also, punishing the press for receiving the information or for soine other offense besides publication slould not have a lower constitutional standard. In fact, the possibility of punishment for receipt without publication would have a greater chilling effect than punishment for publication. Additionally, the government interest is not nearly so strong since the information is not being made public.

97. See note 6 supra and text accompanying.

98. New York Times Co. v. United States, 403 U.S. 713, 717 (1971) (Black, J., concurring). 
public would still be inconsistent with the first amendment. ${ }^{90}$ Protection of the press' first amendunent interests prohibits subsequent punishment without determining the interests of the publisher.

\section{III}

\section{Punishment of Government Employees}

Even when the press cannot be constitutionally prosecuted for receipt or publication of leaked information, the question still remains whether the source of the leak, the government employee, may be prosecuted or fired. If first amendment protection is extended to the leaker as well as to the press, the government employee may have a constitutional defense against adverse action in the employment context as well as against criminal prosecutions for leaking.

The extent of the protection iniglit be conceived by the courts as depending upon whether the government initiates a criminal prosecution or an adverse action. Two arguments might support the differing extent of constitutional protection. First, the uniquely employer interest of the government is weightier in an adverse action against an employee than in a criminal prosecution of the same employee. The government has a stronger justification for firing a disruptive employee than for jailing that einployee. But the greater vulnerability of employees to adverse action in the employinent context than to crimmal prosecution suggests a stronger employee first anendment interest in the face of loss of job or demotion. Second, arguably the employee's loss of job is less grievous than criminal sanctions. However, potential dismissal, like criminal sanctions, inhibits free expression. ${ }^{100}$ For a government employee who leaks information, criminal prosecution is rare and, therefore, loss of job is the greater threat. Day-to-day free exercise of civil liberties depends on a property basis for these rights and a secure job is one of the most necessary property bases. ${ }^{101}$ The Supreme Court lias provided broad protection for first amendment rights of government employees and employees of government contractors from impingement by loss of job. ${ }^{102}$ Thus, both case law and logic suggest that constitutional protection should not vary with the type of sanction the leaker faces.

A threshold question is whether leaking by a government employee

99. This assumes that the classification of the leaked information passes the initial test $i . e$. , that the information is properly classified.

100. Pickering v. Board of Education, 391 U.S. 563, 574 (1968); Kiiskila v. Nichols, 433 F.2d 745, 749 (7th Cir. 1970).

101. Reich, The New Property, 73 Yale L.J. 733 (1964).

102. Pickering v. Board of Education, 391 U.S. 563 (1968); United States v. Robel, 389 U.S. 258 (1967). 
is expression within the meaning of the first amendment. Three arguments can be made that leaking is not protected speech: (1) leaking is conduct rather than expression; (2) the first amendment protects expression of opinion, but not of information; and (3) leaking should be governed by principles of agency law.

That leaking may involve the transmittal of documents in addition to speech and thus may not be "pure speech" suggests an expressionconduct analysis, under which the expression would be protected but not the conduct. ${ }^{103}$ But the traditional rationale supporting the speechconduct analysis is inapplicable to leaks. The expression-conduct analysis is inapplicable to leaks. The expression-conduct dichotomy is applied to limit the form of expression, not the content. ${ }^{104}$ But to cliaracterize leaks as unprotected conduct would in effect be to say that a particular idea can be prevented from being expressed because the leak is a necessary part of the expression. In order to argue that a leak is conduct not protected by the first amendment, the government must demonstrate an interest in preventing the conduct-e.g., the taking of documentsapart from any interest in preventing communication. ${ }^{105}$ However, the government's real concern is in preventing the communication in order to maintain confidentiality. The actual transfer of the document is important only because it is a necessary element of commumication. ${ }^{106}$ Therefore, because the government is attempting to regulate the speech element rather than the conduct element, the non-pure speech analysis is inappropriate.

The second argument that leaking is not protected expression is that a line should be drawn between the expression of opinions, which is protected, and the conveying of information received in confidence, ${ }^{107}$ which, according to this approach, is not. The problem arises when the employee releases documents without comment. Courts, however, have

103. See The Supreme Court, 1970 Term, 85 HARv. L. REv. 199, 210 (1971), suggesting that prosecuting Daniel Ellsberg for leaking the Pentagon Papers to the press is prosecution for conduct and not for expression.

104. United States v. O'Brien, 391 U.S. 367, 376 (1968).

105. The widespread use of electronic copying machines has all but eliminated the threat that the leaking of a document would leave the government without another copy of the document.

106. However, the California Court of Appeal (Second District), in People v. Kunkin, 100 Cal. Rptr. 845 (2d Dist. 1972), rev'd on other grounds, 9 Cal. 3d 245, 507 P.2d 1392, 107 Cal. Rptr. 184 (1973) (see note 86 supra), did draw a distinction between oral communication and the passing of documents because of the greater accuracy of written information and the greater volume of material communicable. This point has some validity, but it is not the type of distinction upon which constitutionality slould turn because it is a bogus distinction. The governmental interest is as much harmed by spoken as by written leaks. This distinction points up the fallacy in the symbolic speech argument.

107. Often, of course, expression of an opinion on a public issue is interwoven with the release of information. 
not yet distinguished between expression of opinions and infornuation in first amendment adjudication. In fact, through this failure to distinguish the courts have neglected the somewhat different issues involved in assuring expression of information. Sources of information are not as widespread as sources of opinion, and the threat against civil liberties that prevents information from becoming public is often more subtle: not criminal punishment or crowd violence, but loss of job. Arguably the expression of information is in greater need of protection through innovative apphication of constitutional directives than is the expression of opinion. Case law and public policy offer no grounds for arguing that the first amendment line sliould be drawn to protect opinion but not information.

The third argument is that, under general principles of agency law, the einployment relationship creates a duty not to disclose information which the employer wishes to keep confidential. The agent is thus under a duty to act solely for the benefit of the principal ${ }^{108}$ and only with authorization. ${ }^{109}$ The Restatement of Agency interprets those rules to mean that an agent is under a duty not to reveal information received in confidence. However, even without constitutional protection the agent may take political stances contrary to the interests of the employer. ${ }^{110}$ Although leaking government information is more closely akin to revealing information received im confidence, it also often involves taking political stances contrary to the interests of the leaker's superiors. And in some cases, at least, the differing political stance may be based on the very information that the government seeks to keep confidential and the enrployee wants to make public.

In addition, the first amendment gives the eniployee added protection in expression when the employer is the state, for first amendment constraints always apply to the government while private entployers are not so restricted. Thus, although principles of agency law miglit reflect the popular traditional concept of government employment, court decisions on the first amendment riglits of government enrployees, rather than agency law, are determinative of whether the employment relationship between the government and civil servants takes the act of leaking information outside the scope of expression protected by the first amendnient.

The courts have yet to articulate a totally coherent and compreliensive theory of the first amendment rights of government employees. Througli the 1950's and 1960's, courts repeatedly stated that public

108. Restatement (SeCOND) of AgenCy $\$ 387$ (1958).

109. Id. $\$ 383$ (adding the proviso, "except when privileged to protect his own or another's interest").

110. Id., § 387, illustration 3 at 202. 
employment cannot be conditioned on the surrender of constitutional rights. ${ }^{111}$ Viewed in light of these pronouncements, United Public Workers $v$. Mitchell, ${ }^{112}$ approving the Hatch Act's restriction on political participation by government employees, ${ }^{113}$ seemed overruled in principle, being based on outdated constitutional concepts. In 1973, however, in U.S. Civil Service Commission v. National Association of Letter Carriers, ${ }^{114}$ the Court reaffirmed its approval of the Hatch Act. The import of this decision was that the Constitution does not forbid the denial to government employees of some rights that are usually considered constitutional rights. Thus, it is important to look at both the purposes of the Hatch Act and the Court's analysis in Letter Carriers to determine what bearing they have on the issue of whether leaking is within the retained first ainendment rights.

Letter Carriers upheld the Hatch Act by balancing the employee's right to participate in partisan politics against the government's interest in promoting fair and efficient government by preventing incumbents from using the Civil Service as a political machine. An equally important consideration was that advancement should not be dependent on currying favor with superiors. The interests that tipped the balance in favor of the government in Letter Carriers do not support the conditioning of government employment on refraining from leaking inforınation. Limiting the partisan political activities permissible for government employees eliminates the incentive for officials who might otherwise pressure subordinates into becoming party functionaries. The Court in Letter Carriers thus was partially balancing the conipeting interests of government employees. These considerations are not present in the issue of leaks because the employees have no interest to be weighed against their freedom to contribute (by leaking) to the public discussion of government policies. Moreover, the Hatch Act did not prohibit all participation in elections by government enployees. The Hatch Act was a legislative decision to condition government employment on abstaining from particular activities as a partisan rather than to condition government employment on abstaining from engaging in partisan activity. Prohibiting leaking curtails expression on the issues of self-government rather than curtailing activity.

111. Pickering v. Board of Education, 391 U.S. 563, 568 (1968); Keyishian v. Board of Regcnts, 385 U.S. 589 (1967); Shelton v. Tucker, 364 U.S. 479 (1960); Wieman v. Updegraff, 344 U.S. 183 (1952).

Most of these cases dealt with employment of "subversives," rather than with the issues involved in leaks such as criticism of one's superiors and unauthorized disclosure. However, the issues are similar: the protected interests of the employee are considered inimical to the interests of the employer.

112. 330 U.S. 75 (1947).

113. 5 U.S.C. $\$ 7324(1970)$.

114. 413 U.S. 548 (1973). 
In fact, the Court's decision in Letter Carriers depended on its interpretation of the Hatch Act as hmiting activities in election campaigns without infringing on the right to vociferously support candidates and political policies. ${ }^{115}$ Letter Carriers upholds a legislative ban on partisan activities not only because of the particular threat that they pose, but also because they are not expression in the first amendment sense. ${ }^{116}$ Unlike activities prohibited by the Hatch Act, however, restrictions on leaking go directly toward prohibiting expression on the issues themselves, a prohibition which the Court in Letter Carriers implied would be unconstitutional. ${ }^{117}$ Thus, punishing leaking might well be inimical to the first amendment, while the Fratch Act is not.

Finally, the Hatcly Act argnably does little to protect either government interest emphasized by the Court in Letter Carriers. Despite the Act, a successful career as a civil servant often depends on supporting the incumbent. Defenders of the practice of allowing the executive branch to enforce political lomogeneity within the bureaucracy argue that this simply requires employees to work in the interests of the government. Actually it is more akin to demanding partisan loyalty. On the other hand, insofar as leaks by employees further the dissemination of informed political opimions in opposition to administration policies, the Letter Carriers rationale supports giving such leaks first amendment protection. Such a policy would discourage the development of a monolithic Civil Service political machine, and an effective Civil Service need not include a requirement that employees adhere to the pohitical beliefs of their superiors.

The Umited States Supreme Court has not decided any cases that considered the extent of first amendment protection for government employees who leak information to the press, but the extent of first amendment protection of government employees who publicly criticize superiors has been the issue in numerous Supreme Court cases. ${ }^{118}$ Criticism-of-superior cases raise most of the same considerations as leak situations. Whether a government employee chooses to influence her agency's policies by releasing information to the press or by directly criticizing the policies through the press, the government employee's interest in participating in the discussion of political issues is the same.

115. 413 U.S. at 575-76, 579; Alderman v. Philadelphia Housing Auth., 496 F.2d 164, 171 (3d Cir. 1974). Letter Carriers further states that the Hatch Act allows full participation in public affairs as long as it does not compromise the efficiency, integrity, and neutrality of the agency. 413 U.S. at 556-57.

116. 413 U.S. at 556.

117. Id. at 567 .

118. Arnett v. Kennedy, 416 U.S. 134 (1974); Pickering v. Board of Education, 391 U.S. 563 (1968); Garrison v. Louisiana, 379 U.S. 64 (1964); Wood v. Georgia, 370 U.S. 375 (1962). 
Similarly, the press' first amendment interest in disseminating ideas from diverse viewpoints as well as the public's interest in liearing expression useful for informed self-government are qualitatively the same for receiving leaked information as for receiving criticism of a government agency by its employee, although arguably the interest is greater for receiving information than opinions. The government's interest in effectively implementing pohicies and in maintaining employee loyalty are similar for leaks and criticism. However, one government interest, that of maintaining security, while being threatened by public criticism of agency officials, is more seriously impaired by information leaks. When the information leak threatens national defense interests or third party privacy rights, the government's security interest is a significant counterweight to the employee's, press', and public's first amendment interests. But in the usual unauthorized leak of information relating to policymaking in a non-national defense context, the government's security interest does not add significantly to the interests in efficient administration and effective policy implementation. Thus, the overall considerations of courts in applying the first amendment should be the same in leak as in criticism situations, but the applicable standard should differ so as to focus on the government's need for confidentiality in leak cases. Accepting in a non-national defense context, the government's security interest to leak cases to provide the starting point for developing the appropriate first amendnient standard for protection of government employees who are threatened with sanctions because they leaked information.

Pickering v. Board of Education ${ }^{119}$ is the Supreme Court case regarding constitutional rights of government employees that is most analogous to the leak situation. It is the leading case defining the first amendment right of a government employee to criticize, through the media, a superior or a policy of her agency. Pickering was a high school teacher who wrote an inflammatory letter to a local newspaper criticizing the Board of Education. The letter disclosed information tending to cast discredit on the policies of the Board of Education, but was found to be somewhat inaccurate in its recitation of facts. The Board of Education sought to fire Pickering, and lie sued for an injunction against the dismissal. The Court held the letter from the teacher to the newspaper to be protected expression within the first and fourteenth amendnents and, accordingly, that adverse action agamst Pickering was constitutionally prohibited because the statements in his letter were not "shown to have been made either with knowledge of their falsity or with reckless disregard for their truth." ${ }^{120}$ In so holding it implied that the New York Times Co. v. Sullivan test is the appropriate standard against

119. 391 U.S. 563 (1968).

120. Id. at 573 . 
which to measure an employee's published criticism of her agency, at least where the employee's criticism does not render impossible her continued effective performance of her job. ${ }^{121}$

Not only are the first amendment interests similar in leak and criticism-of-superior situations, but also the facts of Pickering are close to those typical of leaks. Both Pickering and unauthorized leaks involve publication of information by an employee particularly familiar with an issue and expression that is critical of the agency and that is intended to cause public interference with agency implementation of policy. Also, the Board of Education objected to Pickering's letter because of the information that it provided to the public througl the media. Arguably, a letter to the editor, such as Pickering's, is more likely to be false because the facts recited im such letters typically are not checked for accuracy. Moreover, such a letter might well do more to disrupt the functioning of the agency because the employee's name is associated with it, the information is not integrated into an article which might well seek to balance it with the government's point of view, and the letter is more likely to be written im inflammatory language.

Pickering reflects the constitutional philosophy of the Warren court. Justice Rehnquist's opinion in Arnett v. Kennedy ${ }^{122}$ might imply that the Burger court believes that the rights protected by Pickering must be limited. The Court in Arnett upheld a firing under the LloydLa Follette Act, which permits adverse actions against government employees "for such cause as will promote the efficiency of the service."123 Arnett did not reach the question of what expression by a government employee is constitutionally protected and avoided any confrontation with Pickering by assuming that Kemiedy's criticism was made in reckless disregard of the truth. ${ }^{124}$

The issue that the Court addressed in Arnett was what statutory

121. Solne lower courts have incorrectly interpreted Pickering as holding that a balancing approach is appropriate. E.g., Bean v. Darr, 354 F. Supp. 1157, 1161 (M.D.N.C. 1973).

122. 416 U.S. 134 (1974). Kennedy sought declaratory and injunctive relief against his forner employer, the Office of Economic Opportunity (OEO), after he was fired for publicly stating that the regional director of OEO attempted to bribe a representative of a community action organization. Kennedy argued, first, that the procedure of the firing violated procedural due process protections of the United States Constitution and, second, that the public criticism for which he was fired was expression protected under the first amendment. The three judge district court granted summary judgment for the plaintiff on both causes of action. 349 F. Supp. 863 (IN.D. Ill. 1972), rev'd, 416 U.S. 134 (1974). Because the appeal was froin a grant of summary judgment, the Supreme Court assumed the truth of appellant's allegation that Kennedy's statement was made in reckless disregard of the truth. The Court then held that the facts alleged by the government, if true, justified dismissal under both the statute and the Constitution.

123. 5 U.S.C. $\$ 7501$ (a) (1970).

124. 416 U.S. $139,139-40$. See note 122 supra. 
criteria for adverse actions against a government employee are constitutionally permissible. ${ }^{125}$ The Court avoided the question of what speech by Kennedy is constitutionally protected, and instead interpreted the statute as excluding dismissal for constitutionally protected expression. ${ }^{126}$ Essentially, the Court in Arnett says that the constitutional right of free expression wil be protected when the facts so demand, but that it will not strike down legislative efforts to set administrative standards that both extend and restrict benefits when an employee argues that the legislative restrictions are so broad as to infringe constitutionally protected expression. In that stituation, the Court will simply construe the statute narrowly so that its sanctions may not be apphed to infringe expression protected by the first amendment.

Despite analysis that shows the holding of Arnett to be generally consistent with Pickering on the issue of the first amendment right of government einployees to criticize their superiors, the application of the law by the Arnett Court suggests that the Court was discreetly limiting the right of civil servants to criticize the policies of their agency. ${ }^{127}$ The opimion's lack of sympathy for government employees who criticize their superiors fosters the mipression that the Court would find it acceptable if bureaucrats were able to terminate employees who question agency policy. To the extent that Arnett is so interpreted, the courts would be going beyond the case's holding and its logic, breaking with what should be controlling precedent, and creating bad law and social policy.

The problem is how to develop from Pickering and Arnett the appropriate first ainendment test for sanctions against government einployees who leak inforination. As previously discussed, ${ }^{128}$ the first ainendment interests of the employee, press, and public are qualitatively the saine when an employee criticizes her agency in the media as when she leaks information to the press. The government interest differs to the extent that the unique threat posed by leaks is revelation of confidential information while the umque interest in preventing criticism is that the public presumes that a government einployee is well-informed in her criticisin. Therefore, the knowing-falsehood standard of Pickering is logically related to the government interest being protected. The first

125. The majority accepted the argument that Congress' ability to legislate reform is dependent on the Court's willingness to uphold statutory language as not unconstitutionally vague and overbroad. Justice Relinquist in announcing the judgment of the Court found the Lloyd-La Follette standard of "cause" to be valid because Congress adopted this language as a politically acceptable effort to protect government's power to fire. 416 U.S. at 159 .

126. Id. at 162.

127. Id. at 229 (Marshall, J., dissenting) (stating that Arnett provides no guidance as to what expression is punishable).

128. See text following note 118 supra. 
amendment test that is logically related to the government confidentiality interest threatened by leaking is "knowing or reckless disregard of the likelihood that disclosure will result in serious harm."

The difficulty with the proposed test is in formulating a standard as to what constitutes "serious harm." While prior restraint of the press should only be constitutionally permissible upon a showing of immediate and irreparable harm such as to the defense of the nation, the government employee can be punished for causing "serious harm," a lower requirement. On the other hand, defining "harm" as public opposition to agency implementation of policy is too inclusive and runs counter to the public's interest in receiving information, and is thus too low. Arnett v. Kennedy, discussing the statutory limits on adverse actions against einployees, clarifies the meaning of "harm"-the speech itself inust be the impediment to the agency's functioning. ${ }^{120}$ Even then the government's interest in efficiency can be great enough to overcome the interest in otherwise protected expression only when the expression substantially impedes the agency. Although leaking might undercut office discipline, under Arnett this does not constitute substantial interference with the functioning of the agency. ${ }^{130}$

129. Arnett v. Kennedy, 416 U.S. 134, 162 (1974); accord, Iannarelli v. Morton, 327 F. Supp. 873 (E.D. Pa. 1971), affd, 463 F.2d 179 (3d Cir. 1972); Bean v. Darr, 354 F. Supp. 1157 (M.D.N.C. 1973). Iannarelli was discharged by the National Park Service for using his position to foment disaffection and dissension among fellow employees by falsely stating that their superiors were practicing racial and religious discrimmation. The court held that the government must prove intent to foment or therc would be a chill on his first amendment rights. Intent to foment, although the term itself is not totally clear, does not mean intent to build interest and anger about possible job discrimination, but rather to foment in the sense of trying to disrupt the work environment. That disruption might be the result of raising the issue of job discrimination does not suffice as a justification for an adverse action against the employee, nor does an intent to create disharmony over the issue.

Bean v. Darr is an action by a person disinissed from a position of "Sanitarian II" with the county health department. The Bean court found discussion of methods to improve the efficiency of a government agency to be of public interest and to be constitutionally protected. The fact that the discussion was in the form of criticism by a government employee of her superiors does not change the status of the discussion as constitutionally protected. But the court granted summary judgment for the defendant because the plaintiff's criticism was not an orderly attempt to improve efficiency or expose corruption, but rather involved repeated insubordinate speech, disruptive conduct, and total disregard for office harmony and the rights and feelings of co-workers.

Emerson rejects a "good cause" or "detrimental to the best interests of the service" formulation as the constitutional standard for dismissal of government einployees. He believes that adverse actions are only permissible so long as they are based on employce competence or behavior that impinges on relations within the organization. $T$. $I$. EMERSON, THE SYSTEMS OF FREE EXPRESSION 566-67 (1970).

130. Nebraska Dep't of Roads Employees Ass'n v. Dep't of Roads, 364 F. Supp. 251 (D.C. Neb. 1973), applied this principle holding that criticism of a government employee's superior is protected if there is no close working relationship with the superior and the stateinent meets the New York Times test for falseness. Cf. Lefcourt v. Legal Aid Society, 312 F. Supp. 1105 (S.D.N.Y. 1970), aff'd, 445 F.2d 1150 (2d Cir. 1971); Watts 
Applying the proposed test to three fact situations helps clarify its meaning. First, in the criminal prosecution of Daniel Ellsberg and Anthony Russo for leaking the Pentagon Papers, ${ }^{131}$ it is doubtful that the leak caused serious harm to the defense of the nation. Therefore, Ellsberg and Russo should be constitutionally protected from punishment. Two variables to consider in determining whether the leaker is disregarding the likelihood of harm are: the gravity of the governinent interest threatened and whether the einployee is a sufficiently high level official so that loyalty is particularly important. For exaniple, if the national defense interest had been threatened by the Pentagon Papers, the nature of the interest would have made the threat grave, thus putting Ellsberg and Russo on notice of the potential for harm. Ellsberg and Russo, however, were not in policymaking positions where the government would be especially justified in demanding their personal support for agency progranis. A second fact situation is the leak (presumably by a secretary) to the University of California at Berkeley student newspaper of a copy of a confidential report by the University administration proposing changes in the manageinent and operation of the Umiversity libraries. ${ }^{132}$ The government's interest is in effective implementation of University policy, disruption of which is not as grave as interference with the national defense. The leaking of the report did not itself harm this interest-the immediate danger was only that interested citizens will oppose the agency's progran. Further the leaker was not a pohicymaking official of whoin the University can justifiably denrand a higher standard of loyalty. A third fact situation is the Tuskegee Syphilis Study ${ }^{133}$ which was made public in 1972 after thirty years of allowing black men with syphilis to go untreated. The study was reviewed as recently as 1969 , but did not become public until (presumably) some leaker passed infornation to the press. Publication resulted in termination of the study and payments by the government, but this change in policy and enforced government accountability are exactly the types of harm that are insuffi-

v. Seward School Board, 454 P.2d 732 (Alas. 1969), cert. denied, 397 U.S. 921 (1970), cited in Holstrop v. Board of Junior College Dist. No. 515, 471 F.2d 488, 493 n.12 (7th Cir. 1972).

131. Ellsberg and Russo were indicted for violations of 18 U.S.C. $\$ \$ 371,641$, and 793. These offenses are: conspiracy to defraud the United States, conversion of government property, and transinitting defense information. Ellsberg and Russo were not government employees at the time of the leak of the Pentagon Papers, but rather were employed by a government contractor. This should not affect the level of the first amendment protection because the leak involved government docunients and because it was the government that sought to punish the leakers.

132. Colman, UC Libraries May Merge, Daily Californian, Feb. 2, 1973, at 1. Who leaked the report and whether the leaker was a secretary is unknown.

133. U.S. Dep't of Health, Education and Welfare-Public Health Service, Final Report of the Tuskegee Syphimis Study Ad Hoc Advisory Panel (1973). 
cient to make punishment of the government eniployee constitutionally permissible.

No reported case directly decides the issue of the extent of first amendment protection front sanctions of a government employee who leaks inforniation. The cases that have dealt with related issues have suggested improperly narrow limits on such first amendnient protection. For example, in United States v. Marchetti, ${ }^{134}$ the Fourth Circuit granted the government a preliminary injunction against publication of a former CIA employee's book, which contained classified information. The court found that Marchetti's first amendnient right to criticize the CIA did not include disclosure of confidential information that had been classified, though it did mclude disclosure of nonconfidential information. ${ }^{135}$ The decision allowed court review, but only to determine, first, whether the information censored is actually classified, and second, that it has not previously been released. ${ }^{136}$ The concurring opinion went farther, recognizing that Marchetti's first annendment right should not be sacrificed to arbitrary and self-serving classification of governnent documents and holding open the possibility of judicial review of the reasonableness of the classification. ${ }^{137}$ However, even the concurring opinion mistakenly assumed that reasonable government classification was the standard by which Marchetti's first amendment right should be measured. In Bottcher v. State of Florida Department of Agriculture and Consumer Services, ${ }^{138}$ an action by a government-employed chemist who was given a "conditional" rating by her supervisors because she provided technical information to the Pollution Control Board, the court

134. United States v. Marchetti, 466 F.2d 1309 (4th Cir.), cert. denied, 409 U.S. 1063 (1972). Marchetti is a prior restraint case, but it is appropriately discussed in this section because the government court action was directed against the former government employee. If the constitutional standard is different for prior restraint, the shift is in the einployee's favor, putting a greater burden of proof on the government.

135. However, rather than applying the appropriate constitutional tests to the information, the court, supposedly in deference to the government's strong interest in secrecy, enforced an adhesion contract, Marchetti's secrecy agreement with the government. H. Edgar \& B. Schmidt, Jr., The Espionage Statutes and Publication of Defense Information, 73 CoLUM. L. REv. 929, 1078 (1973). In light of the constitutional limits on the government, not to mentiou principles of contract law, a government einployee cannot be made to surrender constitutional rights through an adhesion contract.

136. United States v. Marchetti, 466 F.2d 1309, 1318 (4th Cir.), cert. denied, 409 U.S. 1063 (1972).

137. Id. at 1318. An opinion like the court's encourages abuse of the classification system. In fact, on remand the District Court found the CIA's censorship to be greatly excessive, and ordered publication without eliminating most of what the CIA had sought to eliminate. For a description of subsequent trial and its findings, see 509 F.2d 1362 (4th Cir. 1975).

138. 361 F. Supp. 1123 (N.D. Fla. 1973). Bottcher leaked the result of chromatographs to another government agency rather than the press, so the first amendment interests might differ from those analyzed in arriving at a first amendment test for efforts by the government to pumish employees who leak information to the press. 
did not reacl the first amendment issue. The court appeared to believe that a government employee could be punislied for failure to obey reasonable regulations on disclosure, although verdict was for the plaimtiff on procedural due process grounds without confronting what substantive criteria are constitutionally permissible. In Bottcher and Marchetti and future cases that arise out of leaks of information by government employees, courts should evaluate the facts in light of the employee's, press', and public's first amendment interests.

\section{CONCLUSION}

Both the courts and the country are presently in a period of tension as to the appropriate moral, legal, and constitutional standards for leaks of government information to the press. For the first time, the role of leaks as generators of news is a subject of widespread public discussion. At the same time, the courts now sporadically adjudicate conflicts surrounding leaks. Court decisions have failed to acknowledge and deal with the new understanding of the social importance of leaks. However, it seems likely that the relationship between the individual dissenter within an institution and the news media will receive increased recognition in judicial opinions. This Comment analyzes existing case law and public policy considerations and suggests guidelines for courts to follow in resolving the legal controversies likely to arise in leak situations.

When a government employee leaks information to a press which subsequently publishes the information, traditional press, public, and government employee first amendinent interests are advanced. In the Pentagon Papers case, the Court held that-despite the government's interests in self-preservation, efficient administration, and confidentiality-the first amendinent interests prohibited a prior restramt on the press' publication. This Comment develops tests by whicl the courts can evaluate these interests not only when the government seeks to restrain publication of leaked information, but also when the government subsequently seeks to pumish the press that published the information or the government employee who leaked it. The courts have not yet fully recognized the significant role of leaks in advancing the public's interest in receiving information useful in self-government and the government employee's interest in free expression. Due to the great vulnerability of government employees and the fragile protection given to the public's right to know, suclı recognition is crucial. 